\title{
LABEL DESIGNING FOR MINIMALLY PROCESSED TILAPIA AIMING THE TRACEABILITY OF THE PRODUCTIVE CHAIN
}

\author{
ERIKA DA SILVA MACIEL* \\ JÚLIA SANTOSVASCONCELOS** \\ LUCIANA KIMIE SAVAY-DA-SILVA *** \\ JULIANA ANTUNES GALVÃO**** \\ JAQUELINE GIRNOS SONATI *****

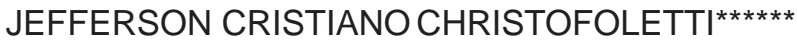 \\ MARÍLIA OETTERER ${ }^{\star \star \star \star \star \star \star ~}$
}

\begin{abstract}
The aim of this study was to develop label for Nile tilapia minimally processed. Analyses were performed to quantify the nutritional components of the fillets; and information about freshness, date of processing and batch specification was collected. Such data were essential for designing labels providing information about the traceability system and presenting codes for quality identification such as the Quick Response Code (QR Code), which allows the electronic encoding of the product on a database. Mandatory food labeling associated with the use of QR Code are tools that convey information to consumers about food quality and the entire production chain. One hundred sixty-two potential consumers were surveyed about the general characteristics of the product packaged in poly nylon film type, vacuum-packed, used for the packaging of traced fresh-cut fillets of tilapia minimally processed and kept under refrigeration $\left(0 \pm 1^{\circ} \mathrm{C}\right)$. According to the Spearman correlation the variables packaging, general appearance and willingness to purchase the product presented a correlation, with coefficients estimated at $0.437,0.466$ and 0.497 respectively.
\end{abstract}

KEY-WORDS: TILAPIA; TRACED FISH; FISH PRODUCTION CHAIN; ELECTRONIC IDENTIFICATION.

\footnotetext{
* Pós Doutoranda, Departamento de Agroindústria, Alimentos e Nutrição, Escola Superior de Agricultura "Luiz de Queiroz", Universidade de São Paulo (ESALQ/USP), Piracicaba, SP, Brasil (e-mail: erikasmaciel@ gmail.com).

** Graduanda em Ciência dos Alimentos, ESALQ/USP, Piracicaba, SP, Brasil (e-mail: julia.vasconcelos31@ gmail.com).

*** Doutoranda em Ciências, Técnica de Laboratório, ESALQ/USP, Piracicaba, São Paulo, Brasil (email: kimie@usp.br).

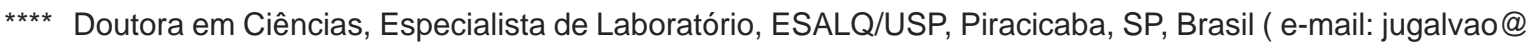
usp.br).

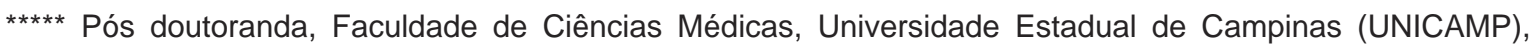
Campinas, São Paulo, Brasil (e-mail: j.girnos@gmail.com).

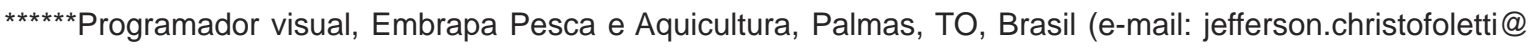
embrapa.br).

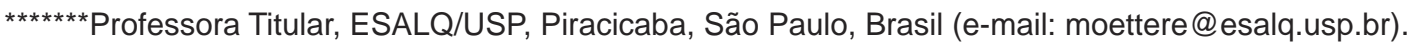




\section{INTRODUCTION}

Food labeling is a powerful tool for consumer education, as information on the label that can contribute to the decision of purchase the product (TAYLOR and WILKENING, 2008). Thus, actions towards effective labeling of foods are important to ensure consciousness regarding food consumption.

The mandatory labeling of foods was introduced in 1990 in the United States and aimed to standardize food labels as means to inform consumers about the nutritional quality of food so that they had choices for healthier products in an attempt to avoid obesity and therefore, the chronic non-communicable diseases (NCDs). Information of food labeling is controlled by the Food and Drug Administration - FDA (OLLBERDING, WOLF \& CONTENTO, 2010).

According to the Brazilian Agency for Sanitary Surveillance (ANVISA) packaged foods must provide general information identifying the product such as product name, ingredients used, amount in grams or milliliters, shelf life and origin (BRASIL, 2005).

Labeling is defined as all inscription, caption, image, graphic or descriptive matter, written, printed, stamped, embossed, lithographed or glued to the food package (BRASIL, 2005). It is noteworthy that labeling is more than just providing information of origin, ingredients and nutritional values of the product. Currently, labeling has also become a tool that helps the tracing in production chain of foods (CAMARA et al., 2008).

Among the most used codes to trace production chain is the barcode, which is an automatic identification tool, available with various applications and has been used for approximately 30 years. It provides accuracy, precision and reliability for automatic and systematic collection of information (BARBOSA NETO and CAMPOS, 2008).

Codes, which can be two-dimensional, whose reading is done through computers or cell phones cameras (Quick Response Code - QR Code), are now commonly used in Europe, Japan, South Korea and China. These codes are able to store more data about the product offered, allowing consumers to obtain more accurate information about the food they purchase (SEINE et al., 2004). Thus, traceability associated with the use of technological tools like the QR Code, may be the answer for safer foods because it can provide much information and transparency of complex production chains, as in the case of fish and therefore ensure quality and safety of products (SCHRÖDER, 2008).

Although there has been a remarkable increase in the consumption of animal products in some countries such as Brazil and China and in other less-developed countries (FAO, 2012), maintaining and ensuring the quality of fish are crucial to increase consumption in the domestic market in Brazil, because among the factors that justify low consumption of fish in Brazil are low quality of the products offered to consumers, as well as cultural aspects and lack of information about the product (FAO, 2009).

Accordingly, there have been efforts to ensure the quality of fish production in Brazil, which led to the growth of aquaculture. An activity that, among those related to food production, has grown over $10 \%$ yearly in ten years, and as such, should embody the role to supply the deficit in fish demand, given that fishing, both at sea and in inland waters, is below half of its potential, with a tendency to stabilize or fall (BRASIL, 2010).

The production of fish in Brazil, for the year 2010 was $1.264 .765 \mathrm{t}$, registering an increase of $2 \%$ compared to 2009, when they were produced 1.240.813 $\mathrm{t}$ of fish. The Northeast region of the country is the one that stands out the most on fish production, with $410.532 \mathrm{t}$, accounting for $32.5 \%$ of national output in 2010 . South, north, east and center-west region, follow, registering $311.700 \mathrm{t}(24.6 \%), 274.015 \mathrm{t}(21.7 \%), 185.636 \mathrm{t}(14.7 \%)$ and 82.881 t (6.6\%), respectively (BRASIL, 2012).

Among the species used in aquaculture, tilapia is considered one of the most promising due to its resistance, fast growth, easy and low-costly feeding (CHHORN and WEBSTER, 2006) and is 
currently one of the most produced fish species in the world, with a production of 333.300 tons in 2010 alone (FAO, 2012).

Global production of tilapia (Oreochromis niloticus) in 2006 was 1.988 .726 tons, generating around US $\$ 2.220 .314 .00$ to the world market. China is emerging as a major producer $(897,276 \mathrm{t})$, and Brazil takes the seventh place (69.078 t) (FAO, 2008).

It is estimated that from 1996 to 2005, tilapia production in Brazil grew at an average of $23 \%$ yearly, affecting international and domestic markets (BRASIL, 2010).

At Brazil, in 2010, tilapia and carp were the most cultivated species, which summed represented $63.4 \%$ of national production of fish this modality, from a continental aquaculture production of 111.145.3 tons in 2008; 132.958.3 tons in 2009 and 155.450.8 tons in 2010 (BRASIL, 2012).

This rising interest on the domestic market can be explained by the fact that tilapia possesses the typical features of fish preference by the consumer, such as white meat, firm texture and delicate flavor, easy filleting and absence of "Y" spines (JORY, ALCESTE \& CABRERA, 2000). Furthermore, the tilapia has valuable nutritional characteristics, is rich in protein, vitamins, and has polyunsaturated fatty acids and low calorific value (FIESP, 2010).

The aim of this study was to develop labeling for Nile tilapia, focusing on traceability of fillets minimally processed, vacuum-packaged in poly nylon film and stored under refrigeration $\left(0 \pm 1^{\circ} \mathrm{C}\right)$.

\section{MATERIAL AND METHODS}

\subsection{ANALYSIS OF COMPONENTS AND TOTAL ENERGY VALUE OF THE PRODUCT}

Analysis of nutritional components of the product was performed in compliance to regulating laws. For that purpose, fillets of Nile tilapia (Oreochromis niloticus) minimally processed, vacuumpacked in poly nylon film package were used to carry out analyses of physical and chemical attributes and shelf life conducted by Savay-da-Silva (2009).

To design the label, the following determinations were made: moisture, total lipids (PREGNOLATTO and PREGNOLATTO, 1985), protein (JOHNSON and ULRICH, 1974), carbohydrates (BRASIL, 2001), ash (PREGNOLATTO and PREGNOLATTO, 1985; WINTERS and TENNYSON, 2005), fatty acids (HARTMAN and LAGO, 1973), lysine and tryptophan (MOORE and STEIN, 1963; SPACKMAN, STEIN \& MOORE, 1958; SPIES, 1967), sodium and iron (HORWITZ, 2005) and cholesterol (SCHMARR, GROSS \& SHIBAMOTO, 1996).

The calculation of total energy intake was estimated considering the conversion factors of Atwater of $4 \mathrm{kcal} / \mathrm{g}$ for protein, $4 \mathrm{kcal} / \mathrm{g}$ for carbohydrates and $9 \mathrm{kcal} / \mathrm{g}$ for lipid (BRASIL, 2001).

\subsection{DATA COLLECTION}

The product, consisting of $200 \mathrm{~g}$ of fillets of tilapia minimally processed, vacuum-packaged and refrigerated $\left(0 \pm 1^{\circ} \mathrm{C}\right)$ (SAVAY-DA-SILVA, 2009) was presented to potential customers. The tests were conducted at three supermarkets, in Piracicaba, São Paulo (Brazil). The interviews were conducted by trained staff that, in agreement with shopkeepers, approached the local people and invited them to participate.

The survey consisted of a questionnaire in which the answers were presented on a Likert scale of 7 points (liked very much, liked, liked a little, neither liked nor disliked, disliked a little, disliked, disliked very much). The survey has allowed assessing general appearance, packaging, color, willingness to purchase, even at higher prices, besides the measurement of attributes concerning 
preference of consumers (MACIEL, 2011).

The project was submitted to the Ethics Committee for Research - Escola Superior de Agricultura "Luiz de Queiroz" (ESALQ) - University of São Paulo (USP) and approved under protocol number 21 (COET/046).

\subsection{IDENTIFICATION OF CODES USED AND FINAL DESIGN OF THE LABEL}

Afterward evaluation, an investigation was conducted to identify the types of existing codes and which code would be more suitable for the study. This step was performed in partnership with GS1 Brazil, in charge of the Coding System of National Products. It was recommended to use barcode associated with DATAMATRIX, a type of QR Code that has standardized data entry, both are consumer-focused and represent more adequately the objective of this research.

\subsection{STATISTICAL ANALYSIS}

Data regarding packaging, acceptance and willingness to purchase were considered for the descriptive and normality analysis. To investigate the relationship between the variables: "packaging", "general appearance", "purchase interest" and "purchase interest even at higher prices", the Spearman correlation coefficient was applied to evaluate possible association relationship between the selected attributes. The statistical software SPSS 15.0 (2006) was used for this analysis.

\section{RESULTS AND DISCUSSION}

The current legislation in Brazil, states that the labeling of foods must contain information on energy values; carbohydrates; protein; total, saturated and trans fat; dietary fiber; sodium; other minerals and vitamins for a certain amount and their corresponding percentage to the daily diet requirements of $2.000 \mathrm{kcal} / \mathrm{day}$ (BRASIL, 2005). Nutritional information on the tilapia fillets (Table 1) showed rich nutritional values.

Overall, fish has good quantity and quality of proteins, the variation among species is between 15 to $25 \mathrm{~g} / 100 \mathrm{~g}$ (CHHORN and WEBSTER, 2006). In this study, was found 17 grams of protein per $100 \mathrm{~g}$ of tilapia fillet, indicating that it is an excellent protein source. These results are similar to those found in other studies (SIMÕES et al., 2007; YANAR, CELIK \& AKAMCA, 2006; SALES and SALES, 1990).

The tilapia fillets minimally processed contain $1.8 \mathrm{~g} / 100 \mathrm{~g}$ of lysine. When compared to other foods of animal origin, fish contains high levels of lysine, which characterizes its high digestibility, acting as an amino acid starter in the digestive process. The average digestibility for fish is $96 \%$, $90 \%$ for poultry and $87 \%$ for cattle. The high digestibility is attributed to the high biological value of the protein. Fish is used to offset the absence of lysine and isoleucine in diets deficient in these substances (OETTERER, 2002).

Values for lipids found in this study are higher than those analyzed by Simões et al. (2007). However, fat content can vary due to age, sex, sexual maturity, diet and season of the year when the fishes were caught (CHHORN and WEBSTER, 2006).

Consumer's interest in relation to food quality has increased and therefore information on the labels of products has received more attention. However, the interpretation of the information is not always efficient and the inclusion of references or control patterns that optimize a better understanding of the food offered to the consumer is suggested, as in the case of using the QR Code (BORGMEIER and WESTENHOEFER, 2009). 
TABLE 1 - NUTRITIONAL VALUE OF TILAPIA FILLETS MINIMALLY PROCESSED, VACUUMPACKAGED AND REFRIGERATED

\begin{tabular}{|c|c|c|}
\hline & $\begin{array}{c}\text { Nutritional information } \\
100 \mathrm{~g} \text { (1 unity) }\end{array}$ & \\
\hline & Content & $\% \operatorname{VD}\left({ }^{*}\right)$ \\
\hline Energy value & $117 \mathrm{kcal}(489 \mathrm{~kJ})$ & 5 \\
\hline Carbohydrates (g) & 0.35 & 1 \\
\hline Proteins (g) & 17 & 23 \\
\hline Total fat (g) & 4.4 & 8 \\
\hline Saturated fat (g) & 1.5 & 7 \\
\hline Monoinsaturated fat $(\mathrm{g})$ & 1.8 & ** \\
\hline Polinsaturated fat (g) & 0.6 & ** \\
\hline Omega $3(\mathrm{~g})$ & 0.03 & ** \\
\hline Omega $6(\mathrm{~g})$ & 0.6 & 3 \\
\hline Trans fat (g) & n.i. & ** \\
\hline Cholesterol (mg) & 58 & ** \\
\hline Total dietary fiber (g) & n.i. & n.i. \\
\hline Sodium (mg) & 29 & 1 \\
\hline Iron (mg) & 0.34 & 2 \\
\hline Other minerals (g) & 1 & ** \\
\hline Lysine (g) & 1.8 & ** \\
\hline Tryptophan (g) & 0.19 & ** \\
\hline
\end{tabular}

Notes: *Daily values based on a diet of $2.000 \mathrm{kcal}$ or $8.400 \mathrm{~kJ}$. Daily values can be higher or lower depending of individual needs. ${ }^{*}$ Non-established daily values of references. $n$.i. $=$ non-identified.

\subsection{TEST WITH CONSUMERS}

Test results with potential consumers indicated $75 \%$ of approval of the packaging and for the overall appearance of the product, $97 \%$ indicated positive acceptance.

The acceptability of a product should be considered optimal when it is above $90 \%$; good, above $80 \%$; moderate, above $70 \%$; and reasonable, above 60\% (MAIA et al., 2008).

Regarding the willingness of the consumer to purchase the product, $83 \%$ were willing to do so. But this number drops to $69 \%$ when the product is considered more expensive. The correlations can be classified according to the calculated coefficients $(r)$ on a scale that ranges from the perfect positive correlation to the perfect negative correlation (LEVIN and FOX, 2004). According to this classification, the results of this study show low positive correlations $(0.10$ to 0.29$)$ and moderate positive $(0.30$ to 0.49$)$, although all are significant at $1 \%$ (Table 2 ).

TABLE 2 - CORRELATION OF SPEARMAN FOR VARIABLES OF THE ACCEPTABILITY TEST

\begin{tabular}{|c|c|c|}
\hline Variables & $\mathbf{R}$ & $N$ \\
\hline Packaging X general appearance I & $0.437(* \star)$ & 162 \\
\hline Packaging $X$ willingness to purchase the product & $0.466(* \star)$ & 162 \\
\hline Packaging $X$ willingness to purchase the product even at higher prices & $0.261(\star \star)$ & 162 \\
\hline General appearance $X$ willingness to purchase the product & $0,497(* *)$ & 162 \\
\hline $\begin{array}{l}\text { General appearance } X \text { willingness to purchase the product even at higher } \\
\text { prices }\end{array}$ & $0,271(* \star)$ & 162 \\
\hline
\end{tabular}

Notes: ** significant correlation at $1 \% . \mathrm{R}=$ correlation coefficient of Spearman. $\mathrm{N}=$ total number of subjects in the sample. 
Variables of packaging, general appearance and willingness to purchase the product showed a stronger association relationship; indicating, therefore, that when packaging acceptance or general appearance approval increases, so does the willingness to purchase the product. However, when willingness to purchase the product even at a higher price is considered, the conventional correlations decrease, indicating that when there is an increase on price, the consumer shows lower interest on buying it.

\subsection{FINAL DESIGN OF THE LABEL}

Once the acceptance of the product was positive, the final design of the label was performed including the results of the fillet analyses and electronic coding, following the labeling standards and standardization proposed by ANVISA (BRASIL, 2005). The Figure 1 shows the final labeling with the highlighted codes.

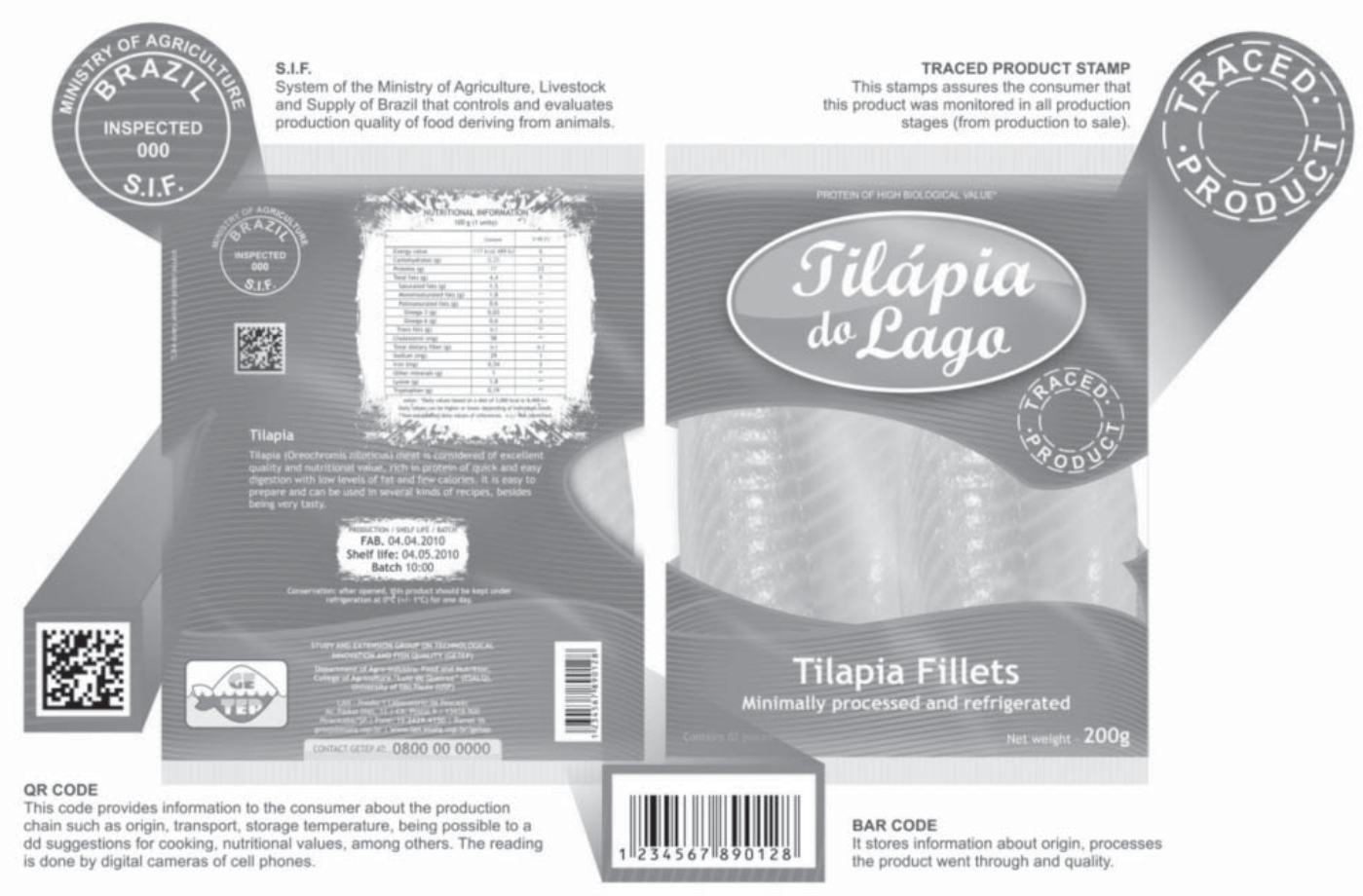

\section{FIGURE 1 - PACKAGE WITH HIGHLIGHTS CONTAINING THE FILLET OF TILAPIA MINIMALLY PROCESSED AND REFRIGERATED}

Food labels should help consumers to make their choice for the product (BORGMEIER and WESTENHOEFER, 2009). The improvement of fish labeling is needed in the market. While the packaging aims at maintaining the quality of the product, the labeling provides the consumer access to information that will help they decide on purchasing it, besides facilitating the process of monitoring and controlling the supply chain.

Food labels are important to provide reassurance to consumers. A study carried out by Gonçalves, Passos \& Biedrzycki (2009) with 162 students (undergraduate and graduate) of Food Engineering course showed that $75 \%$ of respondents had concerns about the fish packaging.

Regarding food safety, the implementing of electronic systems for traceability has been very important because it permits to control the entire chain, monitoring even the environmental conditions to which the food has been exposed (CARTASEGNA et al., 2010).

In research conducted in Brazil, to validate the country's compliance with global trends on food consumption, it was observed that $34 \%$ of respondents considered the trend for convenient/ practical labeling process a priority and $69 \%$ stated that they read the food labels. Among consumers 
who are concerned with a healthy diet and welfare, $37 \%$ underscores fish as an important food source for health (FIESP, 2010).

To ensure traceability of the product through a code that provides security, it was proposed a system based on a combination of 2D codes (QR Code). The system identifies the product, giving it a unique series, which is issued by a server database, and printed in 2D-code on paper or plastic plate.

All information concerning producers, transporters and retailers should be sent via the Internet and stored in the server. The code may be read by cameras, computers or phones that, equipped with a free software program, decode the information (SEINE et al., 2004). Thus, the consumer is able to obtain information about the records of the product with a single operation. The QR Code, developed in this study, contains the suggested information shown in Figures 2 and 3. They are proposals for the use of the QR code to track products by providing information about the production chain and that can be accessible to consumers.

Therefore, the figures contain information about the geographic location of the farm cultivation, the parameters analyzed on the water quality of cultivation, processing and storage temperature and by which the fish passed and microbiological quality of tilapia fillets. There was also the identification of nutritional quality and providing a possible preview of preparation with the filet.

All this information can be provided to consumers in order to build customer loyalty and ensure product safety.

The higher volume of information about the product offered to consumers in addition to providing correlated information not only in terms of the brand name, but also about the technology applied in manufacturing the food and its origin, are factors that tend to alter consumer behavior in choosing and consuming the product (RIBEIRO et al., 2008).

However, there is a large proportion of the population that does not comply with dietary recommendations, particularly those related to the consumption of fish, fruits and vegetables. It is related to inadequate communication strategy. Communication and information focusing on specific audiences resulting in a better positive impact (PIENIAK et al., 2010).

Initiatives aimed at ensuring fish quality are important, including the process to increase household fish consumption which is still below levels recommended by FAO (BRASIL, 2010). High prices and poor quality are still major barriers to fish consumption in Brazil (FAO, 2005, GALVÃO et al., 2010).

Nutritional information as well as data related to the origin, fishery or production, species, shelf life, appearance (gutted, headless, filleted, frozen, refrigerated, thawed) must be clear and comply to legislation. A study conducted in Madrid (Spain) in 285 fish shops of food-markets showed that only $17.2 \%$ of the products was properly labeled in compliance to the laws of that country (ASENSIO and MONTERO, 2008).

English consumers have an interest in the information appearing on the label of fish, including information about its origin, quality and sustainability in the production chain (JAFFRY et al., 2004).

According to Peniak et al. (2008) in Europe was observed that for the costumers most important information on the label of the fish are the specie, shelf life and price, already for Belgian consumers the most important information are those about freshness, shelf life, cooking recommendation and nutritional information.

In China, where fish is a staple diet, consumers are concerned with the lack of safety of food supplied from fisheries (FENG, 2003; ZHOU, 2004).

Consumers understand the importance of the information contained on the label and are more interested in practical information, such as preparation methods, reassurance of safety and quality of the fish brand and its products (PIENIAK et al., 2011).

Fish is a perishable food; therefore, investing in food safety is a promising market niche considering the demand for high-quality products and issues concerning risks for consumers. 



a
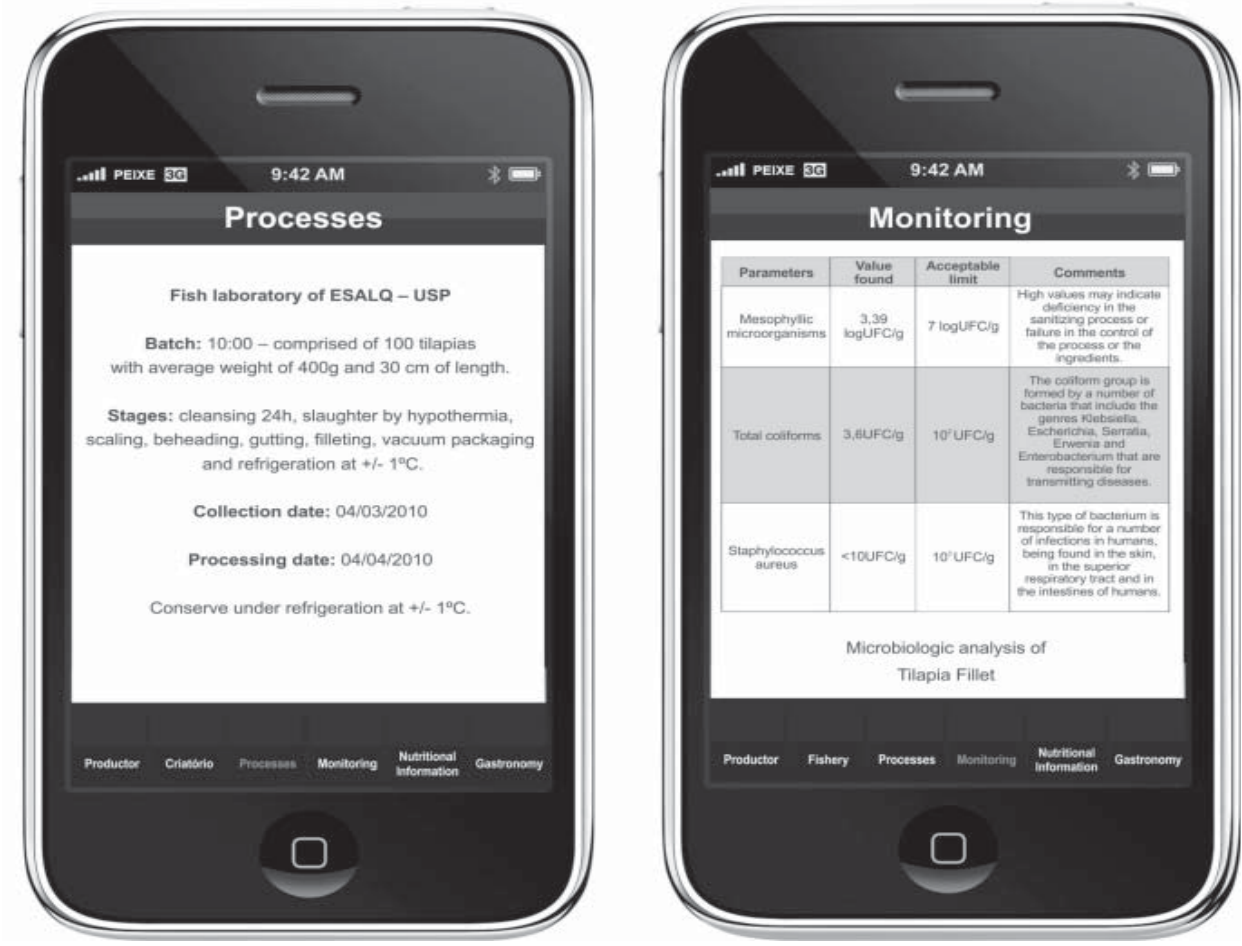

C

\section{FIGURE 2 - EXAMPLES OF DATA VISUALIZATION IN THE PRODUCTION CHAIN}

a) Satellite image of the Palmeiras tilapia farm in Igaratá - SP- Brazil; b) Water quality in the tilapia fishery and standards established by National Council on the Environment (CONAMA) (Brasil, 2005), according to results established by Galvão (2011); c) Tilapia processing according to Savay-da-Silva (2009); and d) Microbial quality of tilapia fillets, according to Savayda-Silva (2009). 


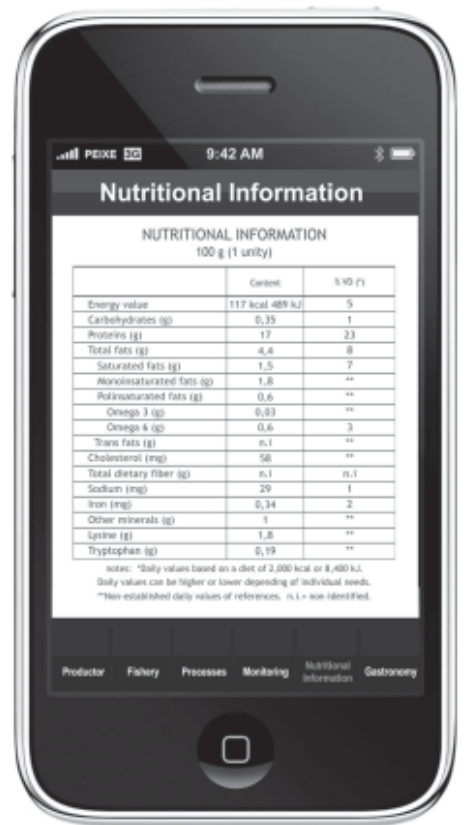

a

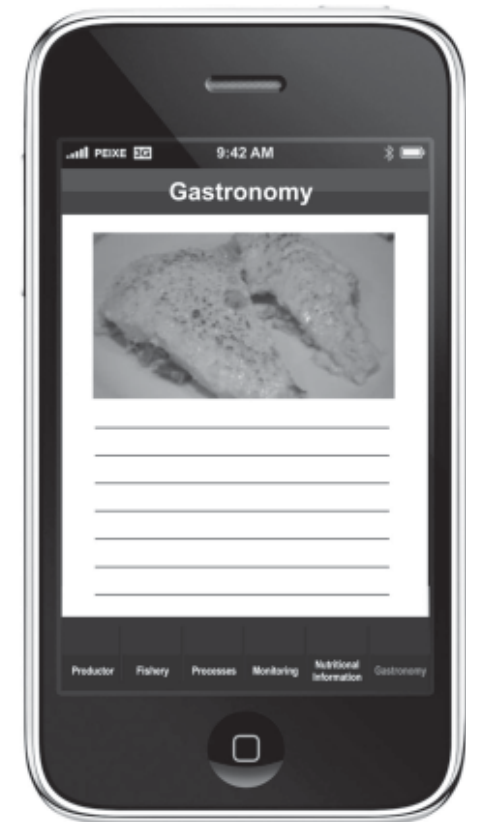

b

\section{FIGURE 3 - EXAMPLES OF DATA VISUALIZATION IN THE PRODUCTION CHAIN}

a) Nutritional information of tilapia fillets used in this research; b) Gastronomic suggestion for the preparation of tilapia fillets minimally processed.

In the fish market, consumers need to have access to thorough and reliable information about its origin and other essential characteristics. Thus, labels have become the unique source of information at the purchase moment, so they must contain relevant data of easy visualization (ASENSIO and MONTERO, 2008).

Changes in global fish market should take into account more detailed and comprehensive monitoring by competent authorities as means to ensure product quality. The development of reliable and sensitive methods for traceability has grown in recent years (SCHRÖDER, 2008). This allows consumers to access record information of the product in a single operation. The QR Code developed in this study contains the suggested information shown in Figures 2 and 3. The use of QR is proposed for tracking product by providing information about the production chain that can be accessible to consumers.

\section{CONCLUSION}

In the present study was observed the influence of the label on the product acceptance; justifying that the investment in this area is a determining factor for the expansion of domestic fish market.

Results suggest that potential customers who approved the overall appearance and packaging of the product also showed willingness to purchase it; therefore, there is a relationship of association between these variables. The same is true regarding the packaging and overall appearance, i.e., respondents who approved the package also appreciated the appearance of the product.

A similar result, but with a less significant relationship, was found between the packaging, appearance and general willingness to purchase the product, even at higher prices.

The design of the label was effective for the purpose of traceability, allowing the consumer to visualize information about the entire production chain. Besides, the product is presented in a practical way, which characterizes it as a product of convenience, in line with market trends. 
The use of QR Code as a label for fish traceability made the difference, allowing the participation of consumers on the tracing system.

\section{RESUMO}

\section{DESENVOLVIMENTO DE ROTULAGEM PARA TILÁPIA MINIMAMENTE PROCESSADA COM FOCO NA RASTREABILIDADE DA CADEIA PRODUTIVA}

O objetivo deste trabalho foi desenvolver rotulagem para tilápia do Nilo minimamente processada. Efetuaram-se análises para quantificar os componentes nutricionais do filé, coletando-se informações sobre sua frescura, data de processamento e as especificações do lote. Esses dados foram fundamentais para a concepção de rótulos com informações sobre o sistema de rastreabilidade e os códigos de identificação de qualidade, como o Quick Response Code (QR Code), que permite a codificação eletrônica do produto em banco de dados. A rotulagem obrigatória dos alimentos associada ao uso de QR Code são ferramentas que transmitem informações aos consumidores sobre a qualidade dos alimentos em toda a cadeia produtiva. Cento e sessenta e dois potenciais consumidores foram questionados sobre as características gerais do filé de tilápia minimamente processado, embalados à vácuo, em filme de nylon tipo poli, rastreados e mantidos sob refrigeração a $0 \pm 1^{\circ} \mathrm{C}$. De acordo com a correlação de Spearman, as variáveis embalagem, aparência geral do produto e o interesse em adqurí-lo apresentaram correlação cujos coeficientes foram estimados em 0,437, 0,466 e 0,497, respectivamente.

\section{PALAVRAS-CHAVES: TILÁPIA; PESCADO RASTREADO; CADEIA DE PRODUÇÃO DE PESCADO; IDENTIFICAÇÃO ELETRÔNICA.}

\section{REFERENCES}

1 ASENSIO, L.; MONTERO, A. Analysis of fresh fish labeling in Spanish fish retail shops. Food Control, v. 19, p-795-799, 2008.

2 BARBOSA NETO, G. E.; CAMPOS, A. A. S. Mobile payment: estudo comparativo entre tecnologias de transações eletrônicas via dispositivos móveis. 2008. 95 p. Available at: URL:http://info.ucsal.br/banmon/Arquivos/Mono_040609.pdf Accessed on: October 8, 2010.

3 BORGMEIER, I.; WESTENHOEFER, J. Impact of different food label formats on healthiness evaluation and food choice of consumers: a randomized-controlled study. Bmc Public Health, London, v.9, n.184, p.1-12, 2009.

4 BRASIL. Ministério da Pesca e Aquicultura. Boletim Estatístico da Pesca e Aquicultura, Brasília, DF. .(2012). Available at: URL: http://www.mpa.gov.br/images/Docs/Informacoes_e_Estatisticas/Boletim\%20Estat\%C3\%ADstico\%20MPA\%20 2010.pdf Accessed on: October 8, 2012.

5 BRASIL. Ministério da Pesca e Aquicultura. Produção pesqueira e aquícola. Brasília, DF. (2010). Available at: URL: http://www.mpa.gov.br/mpa/seap/Jonathan/mpa3/dados/2010/Docs/Caderno\%20Consolidação\%20dos\%20dados\%20 estatiscos\%20final\%20curvas\%20-\%20completo.pdf Accessed on: September 10, 2011

6 BRASIL. Ministério da Pesca e Aquicultura. Consumo per capita aparente de pescado no Brasil 1996-2009. O brasileiro está comendo mais pescado. 2010. Available at: URL: http://www.mpa.gov.br/mpa/seap/Jonathan/mpa3/docs/ folder\%20consumo\%20de\%20pescado\%202009\%202.pdf Accessed on: November 5, 2011.

7 BRASIL. Agência Nacional de Vigilância Sanitária (ANVISA). Gerência Nacional de Alimentos. Rotulagem nutricional obrigatória. Brasília, 2005. Available at: URL: http://www.anvisa.gov.br/rotulo/manual_industria.pdf Accessed on: September 10, 2011.

8 BRASIL. Agência Nacional de Vigilância Sanitária (ANVISA). RDC n. 40, de 21 de março de 2001. Regulamento técnico para rotulagem nutricional obrigatória de alimentos e bebidas embaladas. Brasília, 2001. Available at: URL: http:// www.anvisa.gov.br/legis/resol/40_01rdc.htm Accessed on: October 15, 2011.

9 CÂMARA, M. C. C.; MARINHO, C. L. C.; GUILAM, M.C.; BRAGA, A. M.C.B. A produção acadêmica sobre a rotulagem de alimentos no Brasil. Revista Panamerican Salud Publica, Washington DC, v.23, n.1, p.52-58, 2008.

10 CARTASEGNA, D.; CITO, A.; CONSO, F.; DONIDA, A.; GRASSI, M.; MALVASI, L.; RESCIO, G.; MALCOVATI, P. Smart RFID label for monitoring the preservation conditions of food. Electrical Engineering, New York, v. 54, n. 4, p.381-385, 2010.

11 CHHORN, L.; WEBSTER, C. D. Tilapia: biology, culture and nutrition. New York: Food Products Press, 2006. 678 p.

12 FAO. Food and Agriculture Organization. Feeding pigs in the tropics. 2010. FAO Animal Production and Health, n. 132. Available at: URL: http://www.fao.org Accessed on: October 18, 2011. 
13 FAO. Food and Agriculture Organization. The state of world fisheries and aquaculture (SOFIA). Rome, 2012. p. 209.

14 FAO. Food and Agriculture Organization. The state of world fisheries and aquaculture (SOFIA). Rome, 2009. p. 196.

15 FAO. Food and Agriculture Organization. Fishery and aquaculture statistics. Rome, 2008. 57 p.

16 FAO. Food and Agriculture Organization. Present and future markets for fish and fish products from small scale fisheries in Latin America with a special attention to the cases of Mexico, Peru and Brazil. INFOPESCA, Montevideo, Uruguay, 2005. p 33.

17 FIESP. Federação das Indústrias do Estado de São Paulo. Brasil food trends 2020. São Paulo, 2009. Available at: URL: http://www.brasilfoodtrends.com.br/Brasil_Food_Trends/index.htm Accessed on: November 5, 2011.

18 FENG, W.; JIAN, A.; MU, W.; FU, Z.; ZHANG, X. Consumers' perception toward quality and safety of fishery products, Beijing, China. Food Control, Guildford, v. 20, p. 918-922, 2003.

19 GALVÃO, J. A.; MARGEIRSSON, S.; GARATE, C.; VIDARSSON, J. R.; OETTERER, M. Traceability system in cod fishing. Food Control, Guidford, v. 21, n. 10, p. 1360-1366, 2010.

20 GALVÃO, J. A Rastreabilidade da cadeia produtiva do pescado: avaliação de parâmetros ambientais e sua influência na qualidade da matéria-prima destinada à indústria. 2011. 202 f. Tese (Doutorado em Ciências), Centro de Energia Nuclear na Agricultura, Universidade de São Paulo, Piracicaba, 2011.

21 GONÇALVES, A. A.; PASSOS, M. G.; BIEDRZYCKI, A. A percepção do consumidor com relação à embalagem de pescado: estudo de caso com os alunos do curso de Engenharia de Alimentos. Estudos Tecnológicos, São Leopoldo, v.5, n.1, p.14-32, 2009.

22 HARTMAN, L.; LAGO, R.C.A. Rapid preparation of fatty acid methyl esters from lipids. Lab. Practice, v. 22, n. 8, p. 475476, 1973.

23 HORWITZ, W. (ed.). Official methods of analysis of the Association of Official Analytical Chemists International. $18^{\text {th }}$ ed. Gaithersburg, Maryland: AOAC, 2005. Chapter 50 (Methods 985.35; 984.27).

24 JAFFRY, S.; PICKERING, H.; GHULAM, Y.; WHITMARSH, D.; WATTAGE, P. Consumer choices for quality and sustainability labelled seafood products in the UK. Food Policy, v.29, p. 215-228, 2004

25 JOHNSON, C.M.; ULRICH, A. Analytycal methods. In: SARRUGE, J. R.; HAAG, H.P. Análises químicas em plantas. Piracicaba: ESALQ/ Departamento de Química, Setor Nutrição Mineral de Plantas, 1974. p. 56.

26 JORY, D.E.; ALCESTE, C.; CABRERA, T.R. Mercado y comercialización de tilapia en los Estados Unidos de Norteamérica. Panorama Acuícola, México, v.5, n.5, p.50-53, 2000.

27 LEVIN, J.; FOX, J. A. Estatística aplicada a Ciências Humanas. 9. ed. São Paulo: Pearson, 2004. p. 392.

28 MAIA, M.C.A.; GALVÃO, A.P.G.L.K.; DELLA MODESTA, R.C.; PEREIRA JUNIOR, N. Avaliação do consumidor sobre sorvetes com xilintol. Ciência e Tecnologia de Alimentos, Campinas, v. 28, n. 2, p. 341-347, 2008.

29 MACIEL, E.S. Perspectiva do consumidor perante produto proveniente da cadeia produtiva de tilápia do Nilo rastreada (Oreochromis niloticus) - consumo de pescado e qualidade de vida. 2011. $304 \mathrm{f}$. Tese (Doutorado em Ciências), Centro de Energia Nuclear na Agricultura e no Ambiente, Universidade de São Paulo, São Paulo, 2011.

30 MOORE, I.; STEIN, W.H. Chromatographic determination of amino acids by use of automatic recording equipments. Methods in Enzymology, v.6, p.919-931, 1963.

31 OETTERER, M. Industrialização do pescado cultivado. Guaíba: Editora Agropecuária, 2002. p. 200.

32 OLLBERDING, N. J.; WOLF, R. L.; CONTENTO, I. Food label use and its relation to dietary intake among US adults. Journal of the American Dietetic Association, Philadelphia, v.110, p.1233-1237, 2010.

33 PIENIAK, Z.; MONIKA, K.; KOWRYGO, B.; VERBEKE, W. Consumption patterns and labelling of fish and fishery products in Poland after the EU accession. Food Control, v.22, p. 843-850, 2011.

34 PIENIAK, Z.; VERBEKE, W.; OLSEN, S.O.; HANSEN, K.B.; BRUNSO, K. Health-related attitudes as a basis for segmenting European fish consumers. Food Policy, v.35, p.448-455, 2010.

35 PREgnOLATTO, W.; PREGNOLATTO, N.P. (ed.). Normas analíticas do Instituto Adolfo Lutz: métodos químicos e físicos para análise de alimentos. 3. ed. São Paulo: Instituto Adolfo Lutz, 1985. 533 p.

36 RIBEIRO, M. M.; DELLA LUCIA S. M.; BARBOSA, P. B.F.; GALVÃO, H.L; MINIM, V.P.R. Influência da embalagem na aceitação de diferentes marcas comerciais de cerveja tipo Pilsen. Ciência e Tecnologia de Alimentos, Campinas, v.28, n.2, p. 395-399, 2008. 
37 SALES, R. de O.; SALES, A. M. Estudo da composição química e rendimento de dez espécies de água doce de interesse comercial nos açudes do nordeste brasileiro. Ciências Agronômicas, Ceará, v. 1⁄2, n. 21, p. 27-30, 1990.

38 SAVAY-DA-SILVA, L. K. Desenvolvimento do produto de conveniência: tilápia (Oreochromis niloticus) refrigerada minimamente processada embalada à vácuo e padronização para a rastreabilidade. 2009. 315 f. Dissertação (Mestrado em Ciência e Tecnologia de Alimentos), Universidade de São Paulo, São Paulo, 2009.

39 SCHMARR, H.; GROSS, H. B.; SHIBAMOTO, T. Analysis of polar cholesterol oxidation products: evaluation of a new method involving transesterification, solid phase extraction, and gas chromatography. Journal of Agricultural and Food Chemistry, Washington, v.44, p. 512-517, 1996.

40 SCHRÖDER, U. Challenges in the traceability of seafood. Journal of Consumer Protection and Food Safety, v. 3, p. $45-48,2008$.

41 SEINE, K.; KUWABARA, S.; MIKAMI, S.; TAKAHASHI, Y.; YOSHIKAWA, M.; NARUMI, H.; KOGANEZAKI, K.; WAKABAYASHI, T.; NAGANO, A. Development of the traceability system which secures the safety of fishery products using the QR Code and a digital signature. In: Oceans'04. MTTS/IEEE TECHNO-OCEAN '2004. Japan. Abstract... v. 1, p. 476-481, 2004. Available at: URL<http://ieeexplore.ieee.org/stamp/stamp.jsp?tp=\&arnumber=1402962\&isnumber=30 457> Accessed on: October 5, 2012.

42 SIMÕES, M.R.; RIBEIRO, C.F.A.; RIBEIRO, S.C.; PARK, K. J.; MURR, F.E.X. Composição físico-química, microbiológica e rendimento do filé de tilápia tailandesa (Oreochromis niloticus). Ciência e Tecnologia de Alimentos, Campinas, v. 27 , n. 3, p. 608-613, 2007.

43 SPACKMAN, D.C.; STEIN, W.H.; MOORE, S. Automatic recording apparatus for use in the chromtography of aminoacids. Analytical Biochemistry, New York, v.30, p.1190-1206, 1958.

44 SPIES, J.R. Determination of tryptophan in proteins. Analytical Chemists, v.39, p.1412-1415, 1967.

45 SPSS. Statistical Package for the Social Sciences. User's guide. Base 15.0. Chicago, 2006.

46 TAYLOR, C. L.; WILKENING, V. L. How the nutrition food label was developed, part 2: the purpose and promise of nutrition claims. Journal of the American Dietetic Association, Philadelphia, v.108, p.618-623, 2008.

47 YANAR Y.; CELIK, M.; AKAMCA, E. Effects of brine concentration on shelf-life of hot-smoked tilapia (Oreochromis niloticus) stored at $4^{\circ} \mathrm{C}$. Food Chemistry, v. 97, n. 2, p. 244-247, 2006.

48 WINTERS, S.; TENNYSON, J. Fish and other marine products: aish of seafood. In: HORWITZ, W. (Ed.). Official methods of analysis of AOAC International. $18^{\text {th }} \mathrm{ed}$. Gaithersburg: AOAC International, 2005. Chap. 35 , p. 8.

49 ZHOU, J.H. Consumer's attitude, perception and purchase behavior-case from Jiangsu Province. Journal of China Agricultural Economics, Beijing, v. 11, p. 44-52, 2004.

\section{ACKNOWLEDGEMENTS}

The authors wish to thank the Post-Graduation Program of the Center of Nuclear Energy in Agriculture CENA - University of São Paulo - Piracicaba - São Paulo state, Brazil. Many thanks to CNPq (National Counsel of Technological and Scientific Development) for the scholarship provided to the first author. The authors give thanks to FAPESP (São Paulo Research Foundation) for the financial support. 